\title{
PENTINGNYA KONSEP KESEHATAN SPIRITUAL MASYARAKAT DI MASA PANDEMI COVID-19
}

Kiki Dwi Febriyanti

Kiifeb83@gmail.com

\begin{abstract}
ABSTRAK
Pandemi COVID-19 yang menyebar di seluruh dunia sejak tahun 2019 merupakan wabah terbesar yang menyebabkan banyak dari populasi di dunia kehilangan nyawa serta keluarga yang disayangi, sehingga mengakibatkan ketakutan serta kepanikan bagi seluruh masyarakat di dunia termasuk di Indonesia. Berbagai sikap dan reaksi manusia sangat beranekaragam dalam menyikapi pandemi COVID-19. Pemerintahan negara-negara membuat berbagai kebijakan untuk menangani pandemi COVID-19. Sebagai individu yang beriman, kita harus menciptakan situasi dan kondisi yang membuat kita semakin dekat dengan Tuhan. Oleh karena itu, saya ingin meneliti tentang "Pentingnya Konsep Kesehatan Spiritual Masyarakat di Masa Pandemi COVID-19”.
\end{abstract}

Kata kunci : spiritualitas, masyarakat, Covid-19

\section{PENDAHULUAN}

Wabah virus corona yang menyeba di seluruh dunia dimulai tahun 2019 (COVID19) tidak hanya mengancam fisik penderita, tetapi juga psikososial dan juga termasuk spiritualitas pada masing - masing individu baik penderita maupun terdampak. Penelitian kini mengungkapkan hubungan erat antara kesehatan dan spiritualitas. Di antara populasi yang rentan, spiritualitas memiliki tujuan penting dalam seseorang. Oleh karena itu penting sekali adanya perawatan spiritualitas untuk kesejahteraan manusia (Fides A., 2020).

Saat ini, jarak sosial dianggap efektif untuk mengurangi inefektivitas tinggi penyakit, jadi sebagian besar negara di dunia telah melakukan prosedur ini untuk meminimalkan penularan dan konsekuensi tinggi bagi sistem kesehatan masyarakat (Usher et al., 2020). Jika di satu sisi jarak sosial telah mengurangi tekanan pada rumah sakit tempat tidur, di sisi lain, hal itu telah menimbulkan konsekuensi lain seperti pengangguran, kurangnya tenaga medis dan 
gangguan kesehatan mental (Rogers et al., 2020; Vander Weele, 2020).

Bukti empiris menunjukkan bahwa spiritualitas memiliki kaitan langsung dengan kesejahteraan seseorang. Keyakinan dan praktik biasanya digunakan dalam pengobatan untuk mengatasi penyakit dan perubahan hidup yang membuat stress. Manfaat dari keyakinan spiritual seseorang untuk kesehatan mental dan kesejahteraan memiliki konsekuensi fisiologis yang berdampak pada kesehatan fisik, mempengaruhi risiko penyakit, dan mempengaruhi respons terhadap pengobatan (Fides A., 2020).

Selama masa ini, perawatan spiritual merupakan komponen penting dari kesehatan jiwa, terutama dalam hal mengatasi, menghadapi penyakit, penderitaan, dan akhirnya kematian. Meskipun perawatan spiritual selalu menjadi bagian dari domain keyakinan agama, perspektif yang lebih kontemporer adalah bahwa perawatan spiritual merupakan bagian dari jiwa manusia yang berkaitan dengan pemberian kasih sayang dan empati selama periode stress, kesusahan, dan kecemasan yang meningkat dalam perawatan.

Oleh karena itu, penting sekali memberikan perawatan spiritual sebagai cara untuk mengatasi dan memberikan edukasi betapa pentingnya kesehatan spiritual dimasa pandemi COVID-19 saat ini.

\section{METODE}

metode yang digunakan dalam penulisan ini adalah metode kajian bebas dimana metode ini berwilayah lebih sempit dengan tingkat variasi yang rendah, namun dari penulisan ini dapat berkembang menjadi lebih luas. Metode kajian bebas ini merupakan metode yang dilakukan untuk melakukan penulisan yang dikumpulkan dari beberapa sumber seperti buku teks, buku referensi jurnal dan e-book, dan juga dibandingkan dengan jurnal yang berhubungan dengan "Pentingnya Konsep Kesehatan Spiritual Masyarakat Di Masa Pandemi Covid-19”. Sehingga pembaca dapat mengerti informasi yang sudah ditulis dan dapat memahami pentingnya kesehatan spiritual dimasa pandemi COVID-19.

\section{HASIL}

Pandemi penyakit virus corona 2019 (COVID-19) bukan hanya mengancam kesehatan fisik, tetapi juga telah mengancam kesehatan mental banyak orang. Betapa tidak, penyakit yang telah menelan 53.292 korban jiwa di seluruh dunia hingga 3 April 2020 ini telah menimbulkan banyak kekhawatiran di 
kalangan masyarakat. Setiap menit, masyarakat selalu dihujani oleh berita dan informasi seputar COVID-19, baik melalui TV, media sosial, serta internet. Maka tak heran jika banyak masyarakat mengalami gangguan mental seperti rasa kekhawatiran yang berlebihan di tengah pandemi penyakit yang ditimbulkan oleh virus corona tersebut. Beberapa gangguan mental yang kerap timbul dewasa ini misalnya mudah terbawa emosi, stres, cemas berlebihan, depresi, dan sebagainya. Kecemasan dan gangguan mental ini kemudian akan menimbulkan ketidakseimbangan di otak, yang pada akhirnya timbul menjadi gangguan psikis, atau disebut juga psikosomatik. Ketika seseorang mengalami gejala psikosomatik, maka ia bisa merasakan gejala seperti penyakit COVID-19, yakni merasa demam, pusing, atau sakit tenggorokan, padahal suhu tubuhnya normal.

Spiritualitas adalah area manusia yang selalu ada tetapi, pada saat ini, memungkinkan orang-orang di dalam kurungan mereka untuk melakukan praktik kontemplasi pada tingkat yang lebih esensial. Hal tersebut di atas memungkinkan orang untuk menghadapi situasi yang kompleks isolasi dan juga menemukan diri mereka sendiri, membantu dalam perkembangan mereka dan dalam pencarian mereka arti hidup.
Konsep kesehatan spiritual itu sendiri adalah kontemplasi tentang makna makhluk, yang untuknya perlu melalui berbagai tingkat meditasi spiritual; pergerakan makhluk untuk perjuangan perjumpaan sejati dengan dirinya sendiri. Agar makhluk menemukan dirinya sendiri, pengetahuan diri diperlukan; tetapi pengetahuan diri membutuhkan kontak dengan lebih banyak indra duniawi: ketakutan, ketidakpastian, kehampaan, dan nostalgia, untuk menyebutkan beberapa elemen saja. Setiap gerakan berada di jalan ini harus merenungkan prinsip-prinsip dasar, produk dari refleksi keberadaan dengan dirinya sendiri. Berinteraksi dengan jiwa untuk mencari kebenarannya akan mengungkapkan yang paling agung nilainilai makhluk. Dengan pengetahuan diri, makhluk itu kemudian akan menemukan cara untuk peduli untuk yang lain, mode proxy, minat eksistensial untuk yang lain, sehingga menghasilkan pemahaman diri

Pandemi COVID-19 telah memengaruhi agama dan keyakinan dengan berbagai cara. Banyak batasan telah diterapkan di seluruh dunia. Orang-orang percaya bertentangan dengan peringatan pihak berwenang bahwa pertemuan harus dibatasi untuk memerangi penyebaran virus. Agama selalu memainkan peran sebagai penyegar jiwa, dan partisipasi religius yang teratur 
dikaitkan dengan hasil kesehatan emosional yang lebih baik.

\section{PEMBAHASAN}

Deretan musibah dan bencana alam terus melanda penjuru negri. Pada awal tahun 2020 muncul musibah yaitu merebaknya wabah penyakit yang bernama coronavirus diseases 20192 yang kemudian dikenal dengan sebutan COVID 19. Munculnya COVID 19 sangat menggemparkan dunia. Banyak negara di dunia yang merasa panik atas penyebaran virus ini yang begitu cepat dan cara penularan yang sangat mudah sehingga menelan banyak korban jiwa termasuk di negara Indonesia. Di

Indonesia korban jiwa terus bertambah dari hari ke hari.

Setelah COVID 19 dinyatakan sebagai pandemik oleh WHO, hampir seluruh negara didunia merespon dengan berbagai kebijakan termasuk Indonesia. Pemerintah Indonesia mengeluarkan berbagai kebijakan mulai dari kebijakan di bidang kesehatan,

transportasi dan area publik, pendidikan dan komunikasi publik hingga pemberlakuan PSBB (Pembatasan Sosial Berskala Besar) di berbagai daerah guna menghindari merebaknya penyebaran virus.
Pandemi COVID-19 telah memengaruhi agama dan keyakinan dengan berbagai cara. Banyak batasan telah diterapkan di seluruh dunia. Orang-orang percaya bertentangan dengan peringatan pihak berwenang bahwa pertemuan harus dibatasi untuk memerangi penyebaran virus. Agama selalu memainkan peran sebagai penyegar jiwa, dan partisipasi religius yang teratur dikaitkan dengan hasil kesehatan emosional yang lebih baik.

Di dunia lebih tepatnya di negara Polandia, lebih dari $98 \%$ orang beragama Kristen, tetapi hanya sekitar $82 \%$ yang menganggap diri mereka aktif menjalankan agama mereka. Sisanya mengungkapkan menghadiri kebaktian gereja untuk rasa kewajiban atau kesediaan untuk mewariskan tradisi kepada anak-anak mereka. Masyarakat Eropa modern digambarkan oleh ketidakpedulian terhadap institusi atau ideologi agama dan konsep Tuhan berfungsi sebagai force majeure, takdir atau takdir. Namun, dalam menghadapi penyakit dan penderitaan, perubahan sikap yang signifikan diamati, sebagaimana dibuktikan oleh banyak kesaksian dari para dokter Italia. Kredo dan keyakinan agama tidak hanya memungkinkan kita untuk memahami tetapi juga memengaruhi makna dari banyak peristiwa yang terjadi dalam kehidupan setiap orang. Dengan 
pendekatan ini, iman atau spiritualitas yang dipahami secara luas merupakan kekuatan yang membantu mengatasi krisis mental sekaligus memfasilitasi adaptasi terhadap penyakit atau batasan-batasan yang diakibatkannya.

Spiritualitas dalam konteks perawatan kesehatan adalah bidang yang relatif baru namun menjadi semakin penting. Dalam beberapa tahun terakhir, penelitian telah menunjukkan bahwa keyakinan dan praktik agama dikaitkan dengan berbagai aspek kesehatan, seperti kemampuan untuk mengatasi penyakit, pemulihan setelah dirawat di rumah sakit, dan sikap positif dalam situasi yang sulit, termasuk kesehatan (Albers et al. 2010; Puchalski dkk.2009; Phelps dkk.2009). Oleh karena itu, pentingnya spiritualitas dalam praktik klinis telah disorot (Best et al. 2015). Secara umum, spiritualitas paling sering diartikan sebagai pencarian "pengertian yang lebih tinggi" sehubungan dengan agama atau kepercayaan kepada Tuhan (Mishra et al. 2017). Kebanyakan masyarakat atau orang yang disebut sebagai "orang Barat" telah berhasil belajar untuk menggunakan penderitaan dan dilema moral. Kemudahan dan kenyamanan hidup paling sering menyebabkan kurangnya refleksi serta menyingkirkan pikiran yang mengganggu. Munculnya pandemi Covid-19 telah menimbulkan respon dan reaksi manusia yang berbeda, menguatkan kita dan menyadarkan kita akan kerapuhan keberadaan manusia kita. Kita telah diberi pelajaran tentang kerendahan hati, tetapi kita juga dibarengi dengan perasaan tidak berdaya dan takut.

Saya mendapatkan hasil survei dari (Oliwia Kowalczyk - Journal of Religion and Health) tentang konsep masyarakat masyarakat yang membuktikan bahwa pandemi yang sedang terjadi ini sangat berpengaruh terhadap spiritualitas masyrakat di seluruh duinia. Analisis survei yang dilakukan terhadap 324 peserta menunjukkan bahwa sebagian besar kaum muda, baik perempuan maupun laki-laki, mendominasi. Dalam kelompok anak muda yang berusia antara 21 dan 35 tahun, esensi keimanan sangat penting dan dideklarasikan diiringi dengan seringnya mengamalkan doa. Di Polandia, telah terjadi diskusi tentang krisis iman yang berkembang pada generasi muda dan kurangnya keterikatan mereka pada tradisi gereja. Kelompok survei ini membuat kasus yang sangat menarik untuk dianalisis lebih lanjut karena belum pernah mengalami bencana sosial seperti itu sebelumnya. Riset kami membuktikan bahwa perempuan lebih sering menyatakan menguatkan keyakinan / spiritualitasnya dalam menghadapi bahaya virus corona. Juga penelitian di seluruh dunia menunjukkan bahwa wanita lebih 
sering berpartisipasi dalam kehidupan religius, lebih banyak berdoa atau merasakan kehadiran Tuhan yang lebih besar dalam kehidupan sehari-hari (Forlenza dan Vallada 2018; Peteet et al. 2019; Li et al. 2016).

Alat tersebut mengukur sepuluh dimensi: jenis kelamin, usia, pendidikan, tempat tinggal, keimanan, esensi keimanan dalam hidup, amalan shalat, pentingnya keimanan / spiritualitas sehubungan dengan bahaya virus corona, penguatan keimanan / spiritualitas dalam kaitannya Dengan meningkatnya risiko virus corona, keyakinan bahwa keimanan / spiritualitas akan meningkatkan rasa aman di saat pandemi.

\section{PENUTUP}

\section{Kesimpulan}

Pandemi COVID-19 yang menyebar di seluruh dunia sejak tahun 2019 merupakan wabah terbesar yang menyebabkan banyak dari populasi di dunia kehilangan nyawa serta keluarga yang disayangi, sehingga mengakibatkan ketakutan serta kepanikan bagi seluruh masyarakat di dunia termasuk di Indonesia.

Manfaat dari keyakinan spiritual seseorang untuk kesehatan mental dan kesejahteraan memiliki konsekuensi fisiologis yang berdampak pada kesehatan fisik, mempengaruhi risiko penyakit, dan mempengaruhi respons terhadap pengobatan (Fides A., 2020).

Meskipun perawatan spiritual selalu menjadi bagian dari domain keyakinan agama, perspektif yang lebih kontemporer adalah bahwa perawatan spiritual merupakan bagian dari jiwa manusia yang berkaitan dengan pemberian kasih sayang dan empati selama periode stress, kesusahan, dan kecemasan yang meningkat dalam perawatan.

Agama selalu memainkan peran sebagai penyegar jiwa, dan partisipasi religius yang teratur dikaitkan dengan hasil kesehatan emosional yang lebih baik. Banyak negara di dunia yang merasa panik atas penyebaran virus ini yang begitu cepat dan cara penularan yang sangat mudah sehingga menelan banyak korban jiwa termasuk di negara Indonesia. Dengan pendekatan ini, iman atau spiritualitas yang dipahami secara luas merupakan kekuatan yang membantu mengatasi krisis mental sekaligus memfasilitasi adaptasi terhadap penyakit atau batasan-batasan yang diakibatkannya.

Dalam beberapa tahun terakhir, penelitian telah menunjukkan bahwa keyakinan dan praktik agama dikaitkan dengan berbagai aspek kesehatan, seperti kemampuan untuk 
mengatasi penyakit, pemulihan setelah dirawat di rumah sakit, dan sikap positif dalam situasi yang sulit, termasuk kesehatan (Albers et al. 2010; Puchalski dkk.2009; Phelps dkk.2009).

Saya mendapatkan hasil survei dari (Oliwia Kowalczyk - Journal of Religion and Health) tentang konsep masyarakat masyarakat yang membuktikan bahwa pandemi yang sedang terjadi ini sangat berpengaruh terhadap spiritualitas masyrakat di seluruh duinia.

Juga penelitian di seluruh dunia menunjukkan bahwa wanita lebih sering berpartisipasi dalam kehidupan religius, lebih banyak berdoa atau merasakan kehadiran Tuhan yang lebih besar dalam kehidupan sehari-hari (Forlenza dan Vallada 2018; Peteet et al. 2019; Li et al. 2016).

Alat tersebut mengukur sepuluh dimensi: jenis kelamin, usia, pendidikan, tempat tinggal, keimanan, esensi keimanan dalam hidup, amalan shalat, pentingnya keimanan / spiritualitas sehubungan dengan bahaya virus corona, penguatan keimanan / spiritualitas dalam kaitannya Dengan meningkatnya risiko virus corona, keyakinan bahwa keimanan / spiritualitas akan meningkatkan rasa aman di saat pandemi.

\section{DAFTAR PUSTAKA}

Azania, D., \& Naan, N. (2021). Peran Spiritual Bagi Kesehatan Mental Mahasiswa di Tengah Pandemi Covid-19. HUMANISTIKA: Jurnal Keislaman, 7(1), 26-45.

Buana, Dana Riksa, "Analisis Perilaku Masyarakat Indonesia dalam Menghadapi

Pandemi Virus Corona (Covid19) dan Kiat Menjaga Kesejahteraan Jiwa," Salam: Jurnal Sosial dan Budaya Syar-i, Volume 7, No. 3 (2020)

Dashraath, P., Wong, J. L. J., Lim, M. X. K., Lim, L. M., Li, S., Biswas, A., Choolani, M., Mattar, C., \& Su, L. L. (2020). Coronavirus disease 2019 (COVID-19) pandemic and pregnancy. American Journal of Obstetrics and Gynecology.

Effendi, D. I., Lukman, D., Eryanti, D., \& Muslimah, S. R. (2020). Advokasi psikologis bagi masyarakat terpapar pandemi Covid-19 berbasis religious ECounseling. Advokasi

Psikologis Bagi Masyarakat Terpapar Pandemi Covid-19 Berbasis Religious E-Counseling. 
Embu, A. N. (2020). Pengalaman Postreligius Dan Media Sosial Digital Dalam Praktek Misa Online Di Masa Pandemi Covid19. Jurnal Masalah Pastoral, 8(2), 20-49.

Hapsari, V. C., Sovitriana, R., \& Santosa, A. D. (2021). STRESS PADA PENGEMUDI OJEK ONLINE DI PANDEMIC COVID-19 MASA NEW NORMAL DI JAKARTA. IKRA-ITH HUMANIORA: Jurnal Sosial dan Humaniora, 5(1), 1-10.

Liang, H., \& Acharya, G. (2020). Novel corona virus disease (COVID19) in pregnancy: What clinical recommendations to follow? Acta Obstetricia et Gynecologica

Scandinavica.

Peteet, J. R., Zaben, F. A., \& Koenig, H. G. (2019). Integrating spirituality into the care of older adults. International Psychogeraitrics, 31, 31-38.

Putri, M. A. C. (2021). Perubahan sikap masyarakat pada masa pandemi
COVID-19 di Desa Sambirembe Kecamatan Karangrejo Magetan: tinjauan teori pilihan rasional James S. Coleman (Doctoral dissertation, UIN Sunan Ampel Surabaya).

Ribeiro, M. R. C., Damiano, R. F., Marujo, R., Nasri, F., \& Lucchetti, G. (2020). The role of spirituality in the COVID-19 pandemic: a spiritual hotline project. Journal of Public Health, 42(4), 855-856.

Tri, E., Ameliyaningsih, D. T., \& Kartika, P. (2020). PATUH KEPADA TUHAN ATAU PEMERINTAH? CULTURE SHOCK MASYARAKAT MUSLIM INDONESIA DI TENGAH PANDEMI COVID19. JURNAL ILMIAH SOSIOLOGI AGAMA (JISA), 3(2), 134-146.

Wijayanto, A. ANTOLOGI Adaptasi Kebiasaan Baru Masyarakat Indonesia pada Era Pandemi Pandemi Covid-19: Tinjauan dari Berbagai Disiplin Ilmu. 